\title{
Analisa penilaian tingkat kesehatan koperasi simpan pinjam "Kartini" Kaliurang Pakem, Sleman, Yogyakarta
}

\author{
${ }^{1 *}$ Dwie Yulieanto Saputro, ${ }^{2}$ Mujino \\ ${ }^{1,2}$ Fakultas Ekonomi, Universitas Sarjanawiyata Tamansiswa, Jalan Kusumanegara Yogyakarta 55165 \\ *e-mail korespondensi: dwie.yulieanto@gmail.com
}

\begin{tabular}{l|l}
\hline \hline \multicolumn{1}{c}{ Keywords } & \multicolumn{1}{c}{ Abstract } \\
\hline \hline Capital Aspect, & The purpose of this research was to find out how the health level of the savings and \\
Earning Asset & loan cooperative "Kartini" Kaliurang in 2015 to 2017 was seen from the Capital \\
Quality Aspects, & Aspect, Earning Asset Quality Aspects, Management Aspects, Efficiency Aspects, \\
Management & Liquidity Aspects, Independence and Growth Aspects, Cooperative Identity Aspects. \\
Aspects, Efficiency & This kind of research is descriptive quantitative. The subjects in this research is the \\
Aspects, Liquidity & Savings and Loan Cooperative "Kartini" Kaliurang. The object in this research is \\
Aspects, & the Financial Statements of Savings and Loans Cooperative "Kartini" Kaliurang, \\
Independence and & from 2015 to 2017. The method of collecting data in this research is through \\
Growth Aspects, & documentation techniques. The results showed that the level of health the savings \\
Cooperative & and loan cooperative "Kartini" Kaliurang in 2015 was at the level of Healthy \\
Identity Aspects & Enough, 2016 was at the level of Healthy Enough, 2017 is at the level of Healthy \\
& Enough.
\end{tabular}

\begin{tabular}{|c|c|}
\hline Kata Kunci & Abstrak \\
\hline $\begin{array}{l}\text { Aspek Permodalan, } \\
\text { Aspek Kualitas } \\
\text { Aktiva Produktif, } \\
\text { Aspek Manajemen, } \\
\text { Aspek Efisiensi, } \\
\text { Aspek Likuiditas, } \\
\text { Aspek Kemandirian } \\
\text { dan Pertumbuhan, } \\
\text { Aspek Identitas } \\
\text { Koperasi }\end{array}$ & $\begin{array}{l}\text { Tujuan dari penelitian ini adalah untuk mengetahui bagaimana tingkat kesehatan } \\
\text { koperasi simpan pinjam "Kartini" Kaliurang tahun } 2015 \text { sampai } 2017 \text { dilihat dari } \\
\text { Aspek Permodalan, Aspek Kualitas Aktiva Produktif, Aspek Manajemen, Aspek } \\
\text { Efisiensi, Aspek Likuiditas, Kemandirian dan Aspek Likuiditas. Aspek } \\
\text { Pertumbuhan, Aspek Identitas Koperasi. Jenis penelitian yang digunakan adalah } \\
\text { deskriptif kuantitatif. Subjek dalam penelitian ini adalah Koperasi Simpan Pinjam } \\
\text { "Kartini" Kaliurang. Objek dalam penelitian ini adalah Laporan Keuangan Koperasi } \\
\text { Simpan Pinjam "Kartini” Kaliurang Tahun } 2015 \text { sampai 2017. Metode pengumpulan } \\
\text { data dalam penelitian ini melalui teknik dokumentasi. Hasil penelitian menunjukkan } \\
\text { bahwa tingkat kesehatan koperasi simpan pinjam "Kartini" Kaliurang tahun } 2015 \\
\text { berada pada tingkat Cukup Sehat, tahun } 2016 \text { berada pada tingkat Cukup Sehat, } \\
\text { tahun } 2017 \text { berada pada tingkat Cukup Sehat. }\end{array}$ \\
\hline
\end{tabular}

\section{PENDAHULUAN}

Koperasi merupakan sebuah badan usaha yang mempunyai kegiatan utama pada umumnya yaitu menyediakan jasa penyimpanan dan peminjaman kepada anggota koperasi dengan tujuan memajukan kesejahteraan anggota pada khususnya dan masyarakat pada umumnya. Koperasi dengan tujuannya tersebut tentu saja sangat di harapkan keberhasilannya. Koperasi memiliki arti penting dalam membangun perekonomian nasional, 
tertuang dalam Pasal 33 Ayat 1 Undang-undang Dasar 1945 yang berbunyi, "Perekonomian disusun sebagai usaha bersama berdasar atas asas kekeluargaan." Nama koperasi memang tidak disebutkan dalam pasal 33, tetapi "Asas Kekeluargaan" itu ialah koperasi, dalam (Hendrojogi, 1998; Lestarini, 2013).

Salah satu bentuk koperasi yang umum ditemui di Indonesia yaitu Koperasi Simpan Pinjam (KSP). Dalam Wulandari et al., (2017) Koperasi Simpan Pinjam (KSP) merupakan koperasi yang bergerak dalam pemupukan simpanan dari para anggotanya untuk dipinjamkan kembali kepada anggotanya yang membutuhkan bantuan modal untuk usahanya. Selain itu, Koperasi Simpan Pinjam juga bertujuan mendidik anggotanya bersifat hemat dan gemar menabung serta menghindarkan anggotanya dari jeratan para rentenir. (Subandi, 2011). Sebagai contoh yaitu Koperasi Simpan Pinjam "Kartini” Kaliurang. Dengan berdirinya Koperasi Simpan Pinjam "Kartini" Kaliurang ternyata mampu memberikan solusi bagi pengusaha kecil yang memerlukan dana. Keuntungan yang mereka dapat berupa sistem bagi hasil, dimana jika ada keuntungan dibagi secara adil menurut perjanjian dan jika ada kerugian ditanggung bersama (Hendrojogi, 1998).

Sesuai data yang dikeluarkan oleh Kementerian Koperasi dan UKM, jumlah koperasi di D.I Yogyakarta terhitung selalu meningkat setiap tahunnya. Pada tahun 2013 koperasi yang berdiri di Yogyakarta terhitung sejumlah 2.172 unit, pada tahun 2014 terhitung sejumlah 2.269 unit, dan pada tahun 2015 terhitung sejumlah 2.369 unit. Jika dikalkulasikan menurut Kementerian Koperasi dan UKM jumlah pertumbuhan koperasi di Yogyakarta ratarata sebesar $4.45 \%$ setiap tahunnya.

Dengan data tersebut tentu menimbulkan fenomena baru dalam sektor perkoperasian dan dapat dikatakan persaingan dalam bidang usaha ini semakin ketat. Demi kelangsungan usahanya, tentu pihak koperasi sebisa mungkin untuk terus mengajak orang-orang baik dijadikan sebagai anggota penyimpan ataupun anggota peminjam. Dengan keadaan tersebut masyarakat dituntut semakin cerdas dan semakin berhati-hati untuk memilih koperasi mana yang memang aman dan nyaman untuk menyimpan atau meminjam uang. Untuk mengetahui aman atau tidaknya suatu koperasi salah satu indikator yang dapat digunakan sebagai pedoman adalah dengan mengetahui tingkat kesehatan koperasi (Itang, 2016). Hal inilah yang melatarbelakangi penulis untuk melakukan penelitian tentang Tingkat Kesehatan koperasi guna membantu masyarakat untuk mengetahui tingkat kesehatan koperasi sehingga mempermudah masyarakat dalam menentukan pilihan untuk menyimpan atau meminjam dana dengan aman dan nyaman pada koperasi tersebut (Praya, 2017).

Dalam proses analisa tingkat kesehatan koperasi, peneliti harus menggunakan pedoman atau kaidah yang berlaku (Koperasi, 2016). Pedoman yang dapat digunakan untuk mengkaji Tingkat Kesehatan Koperasi salah satunya dengan perhitungan sesuai Peraturan Deputi Bidang Pengawasan Kementrian Koperasi dan Usaha Kecil dan Menengah Nomor: 06/PER/DEP.6/IV/2016 tentang Tingkat Kesehatan KSP dan USP Koperasi.

Mengacu pada Peraturan Deputi Bidang Pengawasan Kementerian Koperasi dan Usaha Kecil dan Menengah Nomor: 06/PER/DEP.6/IV/2016, perhitungan yang dapat dilakukan guna mengetahui Tingkat Kesehatan Koperasi Simpan Pinjam "Kartini” Kalirang meliputi beberapa aspek perhitungan, diantaranya: Aspek Permodalan, Aspek Kualitas Aktiva 
Produktif, Aspek Manajemen, Aspek Efisiensi, Aspek Likuiditas, Aspek Kemandirian dan Pertumbuhan, dan Aspek Jatidiri Koperasi.

\section{TINJAUAN PUSTAKA}

\section{Koperasi}

Subandi (2011) menyatakan bahwa koperasi didirikan sebagai persekutuan kaum yang lemah untuk membela kepentingan hidupnya, Mencapai keperluan hidupnya dengan ongkos semurah-murahnya, itulah yang dituju. Pada koperasi didahulukan keperluan bersama, buka keuntungan.

Sedangkan definisi yang umum digunakan di Indonesia tercantum dalam UndangUndang Nomor 25 Tahun 1992, yaitu: Koperasi merupakan badan usaha yang beranggotakan orang seorang atau badan hukum koperasi dengan melandaskan kegiatannya berdasarkan prinsip-prinsip koperasi sekaligus sebagai gerakan ekonomi rakyat yang berdasarkan atas asas kekeluargaan (Undang-Undang, 1992).

Sebagaimana dinyatakan dalam Pasal 15 ayat 1 UU No. 25 Tahun 1992, koperasi Indonesia melaksanakan prinsip-prinsip koperasi sebagai berikut:

a. Keanggotaan Bersifat Sukarela Dan Terbuka

b. Pengelolaan Dilakukan Secara Demokratis

c. Pembagian Sisa Hasil Usaha Dilakukan Adil dan Sebanding Dengan Besarnya Jasa Usaha Masing-Masing Anggota.

d. Pemberian balas jasa yang yang terbatas terhadap modalpembagian SHU

e. Kemandirian

Namun tujuan koperasi dapat ditemukan dalam Pasal 3 UU No. 25 Tahun 1992, yang menyebutkan bahwa : Koperasi didirikan dan dikembangkan secara umum bertujuan untuk meningkatkan kesejahteraan ekonomi anggotanya. Berdasarkan pasal tersebut, tujuan koperasi pada garis besarnya meliputi 3 (tiga) hal, yaitu:

a. Memajukan kesejahteraan anggotanya

b. Memajukan kesejahteraan masyarakat

c. Ikut serta membangun tatanan perekonomian nasional

\section{Tingkat Kesehatan Koperasi}

Mengacu pada Koperasi (2016), dalam melakukan penilaian tingkat koperasi sesuai Peraturan Deputi Bidang Pengawasan Kementerian Koperasi dan Usaha Kecil dan Menengah Nomor: 06/PER/DEP.6/IV/2016, perhitungan yang dapat dilakukan guna mengetahui Tingkat Kesehatan Koperasi Simpan Pinjam “Kartini” Kalirang meliputi beberapa aspek perhitungan, diantaranya : Aspek Permodalan, Aspek Kualitas Aktiva Produktif, Aspek Manajemen, Aspek Efisiensi, Aspek Likuiditas, Aspek Kemandirian dan Pertumbuhan, dan Aspek Jatidiri Koperasi. Penetapan predikat tingkat kesehatan KSP dan USP tersebut adalah sebagai berikut: 


\section{Entrepreneurship Bisnis Manajemen Akuntansi (E-BISMA), 1(2), 54-63 \\ Dwie Yulieanto Saputro, Mujino}

Tabel 1

Penetapan predikat tingkat kesehatan

KSP dan USP

\begin{tabular}{cc}
\hline Skor & Predikat \\
\hline $80,00 \leq X \leq 100$ & Sehat \\
$66,00 \leq X<80,00$ & Cukup Sehat \\
$51,00 \leq X<66,00$ & Dalam Pengawasan \\
$<51,00$ & Dalam Pengawasan Khusus \\
\hline
\end{tabular}

Sumber: Peraturan Deputi Bidang Pengawasan MKUKM

Nomor 06/PER/DEP.6/IV/2016

\section{METODE PENELITIAN}

Penelitian yang dilakukan penulis bersifat Deskriptif Kuantitatif yang merupakan usaha untuk menilai dan mengkaji Tingkat Kesehatan Koperasi Simpan Pinjam "Kartini" Kaliurang dengan analisis data-data keuangan yang dimiliki dengan rentang waktu dari tahun 2015 sampai 2017 atau selama 3 (Tiga) periode pelaporan keuangan. Adapun teknik analisis data dalam penelitian ini yaitu menggunakan Teknik Analisis Rasio guna mengetahui tingkat kesehatan yang dimiliki oleh Koperasi Simpan Pinjam "Kartini" Kaliurang (Koperasi, 2016). Analisa penilaian Tingkat Kesehatan Koperasi Simpan Pinjam "Kartini" Kaliurang menggunakan pedoman analisa sesuai dengan Peraturan Deputi Bidang Pengawasan Kementerian Koperasi dan Usaha Kecil dan Menengah Republik Indonesia Nomor : 06/PER/DEP.6/IV/2016 tentang Penilaian Tingkat Kesehatan KSP dan USP Koperasi yang meliputi penilaian terhadap Aspek Permodalan, Aspek Kualitas Aktiva Produktif, Aspek Manajemen, Aspek Efisiensi, Aspek Likuiditas, Aspek Kemandirian Dan Pertumbuhan, dan Aspek Jatidiri Koperasi.

\section{HASIL DAN PEMBAHASAN}

Dengan teknik analisis rasio dan perhitungan sesuai dengan Peraturan Deputi Bidang Pengawasan Kementerian Koperasi dan Usaha Kecil dan Menengah Republik Indonesia Nomor : 6/PER/DEP.6/IV/2016. Menunjukan Koperasi Simpan Pinjam “Kartini” Kaliurang pada perhitungan tahun2015 sampai dengan 2017 berada pada predikat Cukup Sehat dengan jumlah skor yang cukup fluktuatif. Berikut adalah pembahasan dan hasil berhitungan dari setiap aspek yang dijadikan sebagai pedoman dalam penentuan tingkat kesehatan Koperasi Simpan Pinjam “Kartini” Kaliurang.

\section{Aspek Permodalan}

Berdasarkan perhitungan yang telah dilakukan, menunjukan Aspek Permodalan Koperasi Simpan Pinjam "Kartini” Kaliurang pada tahun 2015 sampai tahun 2017 secara keseluruhan dalam posisi yang tidak sehat dengan jumlah skor yang tergolong rendah. Jumlah bobot skor rata-rata yang dapat dicapai sejumlah 5,9 poin (39,3\%).Sebab rendahnya skor yang didapatkan dalam aspek permodalan adalah dalam perhitungan Rasio modal sendiri terhadap total asset dan Rasio Modal Sendiri terhadap Pinjaman Diberikan yang 
Berisiko jumlah modal nilainya tidak sebanding dengan total aset ataupun pinjaman diberikan yang berisiko. Untuk memperoleh jumlah skor yang maksimal cara yang dapat digunakan yaitu dengan menyetarakan jumlah modal sendiri dengan total aset. Beberapa cara untuk meningkatkan modal sendiri yaitu dengan meningkatkan simpanan anggota, simpanan wajib, ataupun simpanan sukarela. Skor berbeda didapatkan dari perhitungan rasio kecukupan modal sendiri, rasio ini berturut-turut menghasilkan skor yang baik dengan total skor yang seluruhnya sempurna yaitu sejumlah 3 poin. Dengan jumlah skor tersebut, dapat dikatakan Koperasi Simpan Pinjam "Kartini” Kaliurang memiliki kemampuan untuk membiayai kegiatan operasional usahanya serta mampu menanggung risiko dari setiap aktiva produktif berisiko yang dimiliki.

Tabel 2

Skor Aspek Permodalan tahun 2015 - 2017

\begin{tabular}{lllll}
\hline Aspek/komponen & $\mathbf{2 0 1 5}$ & $\mathbf{2 0 1 6}$ & $\mathbf{2 0 1 7}$ & Bobot \\
\hline Aspek Permodalan & & & & $\mathbf{1 5}$ \\
\hline a. Rasio Modal Sendiri terhadap Total Asset & 1,5 & 1,5 & 1,5 & \\
b. Rasio Modal Sendiri terhadap Pinjaman Diberikan yang Berisiko & 1,8 & 1,2 & 1,2 & \\
c. Rasio Kecukupan Modal Sendiri & 3 & 3 & 3 & \\
\hline Jumlah Skor Aspek Permodalan & $\mathbf{6 , 3}$ & $\mathbf{5 , 7}$ & $\mathbf{5 , 7}$ & \\
\hline
\end{tabular}

\section{Aspek Kualitas Aktiva Produktif}

Tabel 3

Skor Aspek Kualitas Aktiva Produktif tahun 2015 - 2017

\begin{tabular}{|c|c|c|c|c|}
\hline Aspek/komponen & 2015 & 2016 & 2017 & Bobot \\
\hline Apek Kualitas Aktiva Produktif & & & & 25 \\
\hline $\begin{array}{l}\text { a. Rasio Volume Pinjaman Pada Anggota Terhadap Volume Pinjaman } \\
\text { Diberikan }\end{array}$ & 10 & 10 & 10 & \\
\hline Aspek/komponen & 2015 & 2016 & 2017 & Bobot \\
\hline $\begin{array}{l}\text { b. Rasio Risiko Pinjaman Bermasalah Terhadap Pinjaman yang } \\
\text { Diberikan }\end{array}$ & 4 & 4 & 4 & \\
\hline c. Rasio Cadangan Risiko Terhadap Pinjaman Bermasalah & 5 & 5 & 5 & \\
\hline d. Rasio Pinjaman yang Berisiko Terhadap Pinjaman yang Diberikan & 5 & 5 & 5 & \\
\hline Jumlah Skor Apek Kualitas Aktiva Produktif & 24 & 24 & 24 & \\
\hline
\end{tabular}

Perhitungan Aspek Kualitas Aktiva Produktif dapat dijadikan sebagai tolak ukur untuk menilai tingkat kemungkinan diterimanya kembali dana yang ditanamkan dalam aktiva. Perhitungan dalam aspek kualitas aktiva produktif selama perhitungan dari tahun 2015 sampai dengan tahun 2017 menghasilkan skor cenderung stagnan namun dalam posisi yang baik yaitu sebesar 24 poin $(96 \%)$ dari jumlah bobot skor keseluruhan sebesar 25 poin.Berdasarkan hasil yang diperoleh dari Aspek Kualitas Aktiva Produktif, Koperasi Simpan Pinjam "Kartini" Kaliurang dalam hal ini dapat dikatakan mempunyai orientasi yang baik dalam mengurangi kerugian yang mungkin saja terjadi. Cara yang digunakan tersebut salah satunya dengan melakukan penyisihan kerugian aktiva dengan membuat dana 
cadangan umum menggunakan dana yang diambil dari bagian keuntungan yang menjadi hak Koperasi.

\section{Aspek Manajemen}

Tabel 4

Skor Aspek Manajemen tahun 2015 - 2017

\begin{tabular}{lllll}
\hline Aspek/komponen & $\mathbf{2 0 1 5}$ & $\mathbf{2 0 1 6}$ & $\mathbf{2 0 1 7}$ & Bobot \\
\hline Aspek Manajemen & & & & $\mathbf{1 5}$ \\
\hline a. Manajemen Umum & 3 & 3 & 3 & \\
b. Kelembagaan & 3 & 3 & 3 & \\
c. Manajemen Permodalan & 3 & 3 & 3 & \\
d. Manajemen Aktiva & 3 & 3 & 3 & \\
e. Manajemen Likuiditas & 2,4 & 2,4 & 2,4 & \\
\hline Jumlah Skor Aspek Manajemen & $\mathbf{1 4 , 4}$ & $\mathbf{1 4 , 4}$ & $\mathbf{1 4 , 4}$ & \\
\hline
\end{tabular}

Dalam penilaian Aspek Manajemen Koperasi Simpan Pinjam "Kartini” Kaliurang pada tahun 2015 sampai dengan tahun 2017 tergolong dalam kondisi yang baik terlihat dari seluruh rasio menghasilkan skor yang hampir sempurna yaitu dengan jumlah 14,4 poin (96\%). Hal ini menunjukan Koperasi Simpan Pinjam "Kartini” Kaliurang dapat memenuhi aspek penunjang dari segi sumberdaya manusia dan asset lain terpenuhi dengan baik.

\section{Aspek Efisiensi}

Tabel 5

Skor Apek Efisiensi tahun 2015 - 2017

\begin{tabular}{lllll}
\hline Aspek/komponen & $\mathbf{2 0 1 5}$ & $\mathbf{2 0 1 6}$ & $\mathbf{2 0 1 7}$ & Bobot \\
\hline Aspek Efisiensi & & & & $\mathbf{1 0}$ \\
\hline a. Rasio Beban Operasi Anggota Terhadap Partisipasi Bruto & 4 & 4 & 4 & \\
b. Rasio Beban Usaha Terhadap SHU Kotor & 2 & 3 & 2 & \\
c. Rasio Efisiensi Pelayanan & 2 & 2 & 2 & \\
\hline Jumlah Skor Aspek Efisiensi & $\mathbf{8}$ & $\mathbf{9}$ & $\mathbf{8}$ & \\
\hline
\end{tabular}

Pada Aspek Efisiensi Koperasi Simpan Pinjam “Kartini” Kaliurang memiliki skor yang tergolong sehat, meskipun mengalami sedikit fluktuasi dengan kenaikan yang dialami pada perhitungan tahun 2016 dan kembali turun pada perhitungan tahun 2017. Untuk perhitungan tiap rasio sendiri Koperasi Simpan Pinjam "Kartini” Kaliurang dalam perhitungan rasio beban operasional pelayanan terhadap partisipasi bruto mempunyai skor rasio yang paling baik, dengan jumlah skor sempurna yaitu 4 poin secara berturut-turut. Dengan jumlah skor keseluruhan yang dapat dihasilkan, hal tersebut menandakan kegiatan yang dilakukan Koperasi Simpan Pinjam "Kartini”" Kaliurang telah dilakukan dengan efisien dalam memanfaatkan seluruh aktiva yang dimiliki. 


\section{Aspek Likuiditas}

Tabel 6

Skor Aspek Likuiditas tahun 2015 - 2017

\begin{tabular}{lllll}
\hline Aspek/komponen & $\mathbf{2 0 1 5}$ & $\mathbf{2 0 1 6}$ & $\mathbf{2 0 1 7}$ & Bobot \\
\hline Aspek Likuiditas & & & & $\mathbf{1 5}$ \\
\hline a. Rasio Kas & 5 & 5 & 5 & \\
b. Rasio Pinjaman yang Diberikan Terhadap Dana yang Diterima & 1,25 & 1,25 & 1,25 & \\
\hline Jumlah Skor Aspek Likuiditas & $\mathbf{6 , 2 5}$ & $\mathbf{6 , 2 5}$ & $\mathbf{6 , 2 5}$ & \\
\hline
\end{tabular}

Perhitungan Aspek Likuiditas dapat dijadikan sebagai tolak ukur untuk menilai kemampuan koperasi dalam melunasi kewajiban jangka pendeknya.Dalam pehitungan yang telah dilakukan. Aspek likuiditas Koperasi Simpan Pinjam "Kartini" Kaliurang menghasilkan skor dengan jumlah yang cukup rendah namun masih dalam tingkatan yang cukup sehat. Dengan jumlah skor yang dapat dikatakan cenderung stagnan ini memang sering terjadi pada kebanyakan koperasi simpan pinjam. Sebab, pada umumnya koperasi tidak selalu mengejar profit atau mengabaikan tingkat produktifitas. Jika koperasi ingin mempertahankan tingkat likuiditasnya, salah satu hal yang dapat dilakukan oleh koperasi adalah dengan membatasi tingkat pinjaman. Namun hal itu seperti tidak mungkin, sebab pendapatan yang didapatkan oleh koperasi adalah dengan bunga yang dihasilkan dari pinjaman tersebut. Dilihat dari sisi lain dengan tingkat likuiditas yang rendah tentu pihak yang bertanggung jawab dalam perkoperasian harus mampu untuk menemukan cara agar tingkat likuiditas koperasi meningkat, sebab dengan tingkat likuiditas yang baik tentu koperasi mampu untuk melunasi kewajiban jangka pendeknya serta mampu memenuhi seluruh pinjaman yang dilakukan oleh anggota atau dalam arti lain seluruh aktiva dapat digunakan secara maksimal untuk memenuhi kebutuhan anggota. Namun dengan tingkat likuiditas yang terlalu tinggi juga tidak baik bagi kinerja koperasi, sebab dengan tingkat aktiva yang tinggi tentunya terdapat aktiva yang mengganggur atau tidak tersalurkan. Hal ini tentu menjadi sia-sia sebab pendapatan dari koperasi didapat berdasarkan pinjaman yang dilakukan oleh anggota.

\section{Aspek Kemandirian dan Pertumbuhan}

Tabel 7

Skor Aspek Kemandirian dan Pertumbuhan tahun 2015 - 2017

\begin{tabular}{lllll}
\hline Aspek/komponen & $\mathbf{2 0 1 5}$ & $\mathbf{2 0 1 6}$ & $\mathbf{2 0 1 7}$ & Bobot \\
\hline Aspek Kemandirian dan Pertumbuhan & & & & $\mathbf{1 0}$ \\
\hline a. Rentabilitas Aset & 2,25 & 2,25 & 2,25 & \\
b. Rentabilitas Modal Sendiri & 0,75 & 0,75 & 0,75 & \\
c. Kemandirian Operasional Pelayanan & 4 & 4 & 4 & \\
\hline Jumlah Skor Aspek Kemandirian dan Pertumbuhan & $\mathbf{7}$ & $\mathbf{7}$ & $\mathbf{7}$ & \\
\hline
\end{tabular}


Dalam aspek kemandirian dan pertumbuhan perhitungan aspek didapatkan dari 3 rasio perhitungan, yaitu: Rentabilitas Aset, Rentabilitas Modal Sendiri, dan Kemandirian Operasional Pelayanan. Dilihat dari Rasio Rentabilitas Aset, Koperasi Simpan Pinjam "Kartini" Kaliurang dari perhitungan awal tahun 2015 sampai dengan tahun 2017 menghasilkan skor yang baik dengan jumlah 2,25 poin. Perhitungan Rasio rentabilitas modal sendiri tercatat dari perhitungan tahun 2015 sampai dengan tahun 2017 menghasilkan skor tetap yaitu sejumlah 0,75 poin dan dalam hal ini rasio rentabilitas modal sendiri dari tahun 2015 sampai dengan tahun 2017 termasuk dalam kriteria rendah. Rasio Rentabilitas Modal Sendiri Menghasilkan skor dengan jumlah yang rendah disebabkan karena jumlah SHU yang dibagikan kepada anggota jumlanya sangat kecil jika dibandingkan dengan total modal sendiri. SHU bagian koperasi memiliki nilai yang kecil sebab pihak koperasi lebih memilih SHU yang dimiliki lebih banyak disalurkan sebagai dana cadangan umum. Hal ini dimaksudkan untuk meminimalisir risiko yang sewaktu-waktu dapat terjadi. Sedangkan dalam perhitungan rasio kemandirian operasional, Koperasi Simpan Pinjam "Kartini" Kaliurang mendapatkan skor sempurna secara berturut-turut yaitu sejumlah 4 poin. Analisis yang dapat dilakukan dari total skor yang didapatkan dalam aspek kemandirian dan pertumbuhan Koperasi Simpan Pinjam "Kartini" Kaliurang mengindikasikan bahwa koperasi dapat dikatakan belum mampu menghasilkan rentabilitas secara maksimal namun untuk kemampuan dalam memenuhi operasional pelayanan dalam kegiatan perkoperasian sudah menunjukan dalam kinerja yang baik.

\section{Aspek Jatidiri Koperasi}

Tabel 8

Skor Aspek Jatidiri Koperasi tahun 2015-2017

\begin{tabular}{|c|c|c|c|c|}
\hline Aspek/komponen & 2015 & 2016 & 2017 & Bobot \\
\hline Aspek Jatidiri Koperasi & & & & 10 \\
\hline a. Rasio Parisipasi Bruto & 7 & 7 & 7 & \\
\hline b. Rasio Promosi Ekonomi Anggota (PEA) & 3 & 3 & 3 & \\
\hline Jumlah Skor Aspek Jatidiri Koperasi & 10 & 10 & 10 & \\
\hline
\end{tabular}

Aspek Jatidiri Koperasi dalam perhitungan yang telah dilakukan pada tahun 2015 sampai tahun 2017 menunjukan skor yangsangat baik, yaitu dengan jumlah skor maksimal sebesar 10 poin secara berturut-turut. Dengan nilai sempurna tersebut menunjukkan bahwa Koperasi Simpan Pinjam "Kartini" Kaliurang dalam melayani anggotanya memiliki kemampuan yang tergolong tinggi. Selain itu, koperasi juga dapat dikatakan telahmenunjukkan kemampuan yang cukup baik dalam memberikan manfaat efisiensi partisipasi dan manfaat efisiensi dalam pembiayaan koperasi. 


\section{Perkembangan Penetapan Tingkat Kesehatan Koperasi Simpan Pinjam "Kartini" Kaliurang}

Tabel 9

Rekapitulasi Skor Penilaian Tingkat Kesehatan Koperasi Simpan Pinjam "Kartini”

Kaliurang Tahun 2015-2017

\begin{tabular}{lllll}
\hline Aspek/komponen & $\mathbf{2 0 1 5}$ & $\mathbf{2 0 1 6}$ & $\mathbf{2 0 1 7}$ & Bobot \\
\hline Aspek Permodalan & 6,3 & 5,7 & 5,7 & \\
Aspek Kualitas Aktiva Produktif & 24 & 24 & 24 & \\
Aspek Manajemen & 14,4 & 14,4 & 14,4 & \\
Aspek Efisiensi & 8 & 9 & 8 & \\
\hline & & & & \\
\hline Aspek/komponen & $\mathbf{2 0 1 5}$ & $\mathbf{2 0 1 6}$ & $\mathbf{2 0 1 7}$ & Bobot \\
\hline Aspek Likuiditas & 6,25 & 6,25 & 6,25 & \\
Aspek Kemandirian dan Pertumbuhan & 7 & 7 & 7 & \\
Aspek Jatidiri Koperasi & 10 & 10 & 10 & \\
Total Skor & $\mathbf{7 5 , 9 5}$ & $\mathbf{7 6 , 3 5}$ & $\mathbf{7 5 , 3 5}$ & \\
\hline
\end{tabular}

Pada tahun 2015 diketahui tingkat kesehatan Koperasi Simpan Pinjam "Kartini" Kaliurang memiliki jumlah skor sebesar 75,95 poin. Dengan jumlah tersebut menempatkan Koperasi Simpan Pinjam "Kartini” Kaliurang pada predikat Cukup Sehat.Pada tahun 2016 tingkat kesehatan Koperasi Simpan Pinjam “Kartini” Kaliurang mengalami sedikit kenaikan skor dengan jumlah skor yang didapat sebesar 76,35 poin. Meskipun mengalami kenaikan skor, predikat yang didapatkan tidak berubah atau masih sama dalam tingkatan Cukup Sehat.Pada tahun 2017 jumlah skor yang didapatkan oleh Koperasi Simpan Pinjam "Kartini" Kaliurang sejumlah 75,35 poin. Dengan jumlah tersebut Koperasi Simpan Pinjam "Kartini" Kaliurang berada pada level predikat Cukup Sehat.

\section{KESIMPULAN DAN SARAN}

Berdasarkan hasil analisis data dan perhitungan sesuai Peraturan Deputi Bidang Pengawasan Kementerian Koperasi dan Usaha Kecil dan Menengah Nomor: 6/PER/DEP.6/IV/2016, guna mengetahui Tingkat Kesehatan Koperasi Simpan Pinjam "Kartini" Kaliurang dapat diketahui bahwa Kinerja Koperasi Simpan Pinjam "Kartini" Kaliurang selama kurun waktu tahun 2015 sampai tahun 2017 dapat dikategorikan kedalam tingkatan Cukup Sehat dengan rentang skor yang tidak terlalu signifikan setiap tahunnya. Dalam prosesnya, kinerja Koperasi Simpan Pinjam "Kartini" Kaliurang menunjukan progres yang cukup baik. Namun dalam beberapa Aspek perhitungan menunjukan jumlah skor yang cukup rendah. Beberapa aspek yang digunakan dalam perhitungan penilaian tingkat kesehatan Koperasi Simpan Pinjam "Kartini" Kaliurang belum mampu menghasilkan skor yang cukup baik diantaranya, adalah dalam Aspek Permodalan dan Aspek Likuiditas.Aspek Permodalan secara keseluruhan berada pada kondisi yang tidak sehat, kondisi ini disebabkan dari rendahnya rasio modal sendiri. Aspek Kualitas Aktiva Produktif Koperasi Simpan Pinjam "Kartini” Kaliurang berada pada kondisi Sehat, hal ini 
mengindikasikan koperasi mampu menutup setiap aspek risiko dengan baik. Aspek manajemen menghasilkan skor yang cenderung stagnan namun dengan kondisi yang sehat, dengan itu dapat dikatakan koperasi telah memenuhi aspek penunjang dengan cukup maksimal. Aspek efisiensi memperoleh skor yang baik dan berada pada kondisi sehat. hal ini menunjukan jika koperasi telah menjalankan usahanya dengan efisien. Aspek likuiditas secara keseluruhan memiliki skor yang rendah, hal ini disebabkan dari rendahnya dukungan modal sendiri yang diberikan oleh anggota. Aspek kemandirian dan Pertumbuhan berada pada kriteria cukup baik, hal ini mengindikasikan koperasi memiliki kemandirian yang baik dalam memenuhi operasional pelayanannya secara maksimal. Aspek jatidiri koperasi termasuk dalam kondisi yang Sehat dengan jumlah skor maksimal, Dengan nilai sempurna tersebut menunjukkan bahwa Koperasi Simpan Pinjam "Kartini” Kaliurang dalam melayani anggotanya memiliki kemampuan yang tergolong tinggi. Untuk meningkatkan kualitas kesehatan koperasi, pihak yang bertanggung jawab harus mampu menjaga aspek-aspek perkoperasian. Dalam hal ini Pengurus harus selalu memperhatikan tingkat laju keuangannya seperti aset yang dimiliki dan modal sendiri. Sebab aktiva yang senantiasa baik maka kinerja koperasi akan semakin maksimal dan tingkat kesehatan koperasi dapat terus meningkat dan dapat terus bertahan pada tahun berikutnya.

\section{DAFTAR PUSTAKA}

Hendrojogi (1998). Koperasi azas-azas, teori dan praktek. PT Raja Grafindo Persada: Jakarta.

Itang (2016). Badan Usaha Koperasi dan Badan Usaha Non Koperasi (Studi Komparatif). Jurnal Ekonomi Keuangan dan Bisnis Islam, 7(1), 53-76.

Koperasi (2016). Peraturan Deputi Bidang Pengawasan Kementerian Koperasi dan Usaha Kecil dan Menengah Republik Indonesia Nomor: 6 /Per/Dep.6/IV/2016. Kementerian Koperasi dan Usaha Kecil dan Menengah Republik Indonesia.

Lestarini, R. (2013). Pasal 33 Undang - Undang Dasar Negara Republik Indonesia Tahun 1945 dan Penerapannya dari Masa ke Masa sejak Era Pemerintahan Soekarno, Soeharto, dan Pemerintahan Era Reformasi. ADIL : Jurnal Hukum, 4(1), 37.

Wulandari, Mei \& Gundo, Entri Sulistari (2018). Strategi Pengembangan Koperasi (Studi Kasus Pada Koperasi Simpan Pinjam Mentari dan Mandiri Salatiga), Jurnal Ecodunamika, 1(1), 1-6.

Praya, L. G. A. (2017). Analisis Kinerja Keuangan Koperasi Simpan Pinjam dan Pembiayaan Syariah BMT Dana Insani Wonosari Tahun 2013-2015. Universitas Negeri Yogyakarta.

Subandi (2011). Ekonomi Koperasi. Alfabeta: Bandung.

Undang-Undang Republik Indonesia (1992). Undang-Undang Republik Indonesia Nomor 25 Tahun 1992 tentang Perkoperasian. 